\title{
Effect of indoxacarb against tomato fruit borer (Helicoverpa armigera Hub.) and phytotoxicity to tomato plants
}

\begin{abstract}
Present study was undertaken at Crop Research Centre of G.B.U.A\&T., Pantnagar to evaluate the effect of Indoxacarb against $\mathrm{H}$. armigera in tomato. The percent damage of fruits by H. armigera was observed in Indoxacarb 75 and $60 \mathrm{~g}$ a.i./ha dosage with 7.0 and 8.0 per cent fruit damage. Indoxacarb $50 \mathrm{~g}$ a.i./ha was at par with Chlorpyrifos having 14.66 and 11.83 per cent fruit damage, respectively. Indoxacarb at 30 and $40 \mathrm{~g}$ a.i. /ha though had significantly lesser fruit damage 18.33 and 17.50 , respectively but these dosage were less effective compared to Chlorpyrifos. As far as percent fruit damage over the untreated control is concerned maximum reduction in damage $(83.17 \%)$ was obtained with Indoxacarb $75 \mathrm{~g}$ a.i./ha followed by Indoxacarb $60 \mathrm{~g}$ a.i./ ha $(71.89 \%)$, Chlorpyrifos $(58.56 \%)$. Indoxacarb at 30,40 and $50 \mathrm{~g}$ a.i./ha reduced the per cent damage by $35.94,40.57$ and 48.72 per cent respectively. Indoxacarb treated treatments at 60 and $70 \mathrm{~g}$ a.i./ha dosage yielded the highest yield of marketable fruits 29.16 and 29.50 tons/ha respectively. While in untreated control, it was 16.66 tons/ha. All the treatments treated with Indoxacarb including 150 and $250 \mathrm{~g}$ a.i./ha dosage did not show phytotoxic effect. The considering larval control, damage to the fruits and ultimately the yield of marketable fruits as well as plant safety, Indoxacarb can be used at 60 or $75 \mathrm{~g}$ a.i. /ha dosage.
\end{abstract}

Keywords: helicoverpa armigera, bollworm, tomato, indoxacarb, phytotoxicity
Volume 3 Issue 2 - 2016

\author{
Wajid Hasan, Chhibber RC, Singh CP \\ Department of Entomology, GB Pant University of Agriculture \& \\ Technology, India
}

\begin{abstract}
Correspondence: Wajid Hasan, Department of Entomology, GB Pant University of Agriculture \& Technology, India, Tel
\end{abstract} 00917677466479,Email entowajid@gmail.com

Received: December 22, 2015 | Published: March 14, 2016

\section{Introduction}

The bollworm, Helicoverpa armigera Hübner (Lepidoptera: Noctuidae), a highly polyphagous species, ${ }^{1,2}$ and a pest of major economic importance on a wide range of crops, particularly cotton, soybeans, tobacco, chickpea and pigeonpea. ${ }^{3,4}$ The polyphagous pest of worldwide occurrence inflicting annual crop damage in India worth US \$1 billion. ${ }^{5}$ This pest accounts for the consumption of half of the total insecticide used in India for protection of different crops. ${ }^{6}$ H. armigera is one of the important and key pests in tomato fields in India, ${ }^{7}$ loss in tomato yield to the tune of 50 to 80 per cent. ${ }^{8}$ In Tamil Nadu, losses of fruit range 40-50\%. ${ }^{9}$ Similarly, in Northern India, 30\% loss of the fruit was observed due to tomato fruit worm. ${ }^{10}$ Selvanarayanan et al., ${ }^{11}$ reported $5-55 \%$ losses from this insect pest in the tomato growing areas of India. Tomato fruit worm has also caused $35 \%$ yield loss in tomato ${ }^{12}$ and $37.79 \%$ specifically in Karnataka, India. ${ }^{7}$ Indoxacarb is an oxadiazine insecticide that blocks the sodium channels in insect nerve cells, causing lepidopteran larvae to stop feeding within 4hours, become paralyzed and die within 2 to 5 days. ${ }^{13}$ It is more effective as a stomach poison than as a contact poison. Indoxacarb is fairly selective, having activity primarily against lepidopteran larvae and certain species of sucking insects such as Lygus bugs. However, the activity of indoxacarb against the sucking insects is weaker than for Lepidoptera because of its slower bioactivation, lower sensitivity and a less favorable method of oral uptake in the sucking insects. Indoxacarb allows most predators and immature wasp parasites to survive. ${ }^{14,15}$
The present investigation was therefore undertaken to test the effectiveness of Indoxacarb to control controlling $H$. armigera in tomato in comparison to chalorpyriphos.

\section{Materials and methods}

The present investigations were carried out at Crop Research Centre of G. B. Pant University of Agriculture \& Technology, Pantnagar-263145, Uttarakhand (India). During cropping season (2008-2009) maximum temperature $\left(28-35^{\circ} \mathrm{C}\right)$, minimum temperature $\left(15-21^{\circ} \mathrm{C}\right)$, maximum relative humidity $(80-92 \%)$ and minimum relative humidity $(50-55 \%)$ were observed. Present study was undertaken to control the $H$. armigera in tomato variety Pant T-3. Two spraying of Indoxacarb 14.5 SC(@30,40, 50, 60 and 75g a.i./ha) and Chlorpyrifos20 EC (@500g a.i./ha) was done on the appearance of insect, at flowering/fruit setting stage. The tomato variety, Pant Type3 was sown in $5 \times 4.8 \mathrm{~m}$ plot size at row and plant density of $60 \times 50 \mathrm{~cm}$, replicated thrice. The space between treatments and replication were $1 \mathrm{x} 1.5 \mathrm{~m}$ taken. The total seven treatments were taken i.e. Indoxacarb 14.5 SC@30g a.i./ha, Indoxacarb14.5 SC@40g a.i./ha, Indoxacarb 14.5 SC@50g a.i./ha, Indoxacarb14.5 SC @60g a.i./ha, Indoxacarb 14.5 SC@75g a.i./hac, Chlorpyrifos20 EC@500g a.i./ha and one (control). The spray volume was $400 \mathrm{lit} / \mathrm{ha}$, hollow cone type nozzle and sprayed the crop two times. Separate treatments of $6 \times 6 \mathrm{~m}^{2}$ were sprayed with Indoxacarb 14.5 SC@150 and 250g a.i./ha to observe phytotoxic effect on leaves, flowers and fruits. The spray was done on the appearance of insect and at flowering and fruit setting stage (Appendix 1). 


\section{Larval count}

Larvae were counted from five marked plants on apical shoots, leaf lets, flowers, flower calyses as well as fruits. The observation were recorded one day before spray, 3,5,7 and 15days after spray.

\section{Fruit damage}

Fruits were picked from net plot area i.e leaving each border row as well as one boarder plant in each row. Healthy and damaged fruits were counted to complete cumulative damage in terms of per cent damaged fruits by $H$. armigera.

\section{Yield}

Ripe fruits were picked and weight of healthy fruits was recorded from net plot area from each plot and total yield in terms tons/ha was completed.

\section{Phytotoxicity}

All the above ground plant parts were observed for leaf scorching, plant deformity, fruit deformity and flower deformation in each plot treated with Indoxacarb 14.5 SC @ 150 and 250g a.i./ha dosage.

\section{Data analysis}

All the data were subjected to the analysis of variance in RBD. Larval counts were analyzed with original as well as square root transformation. Data on per cent damaged fruits was analyzed be in terms of original as well as angular transformation. Yields of marketable fruits was analyzed by simple RBD with original figures in terms o tons/ha (Figure 1).

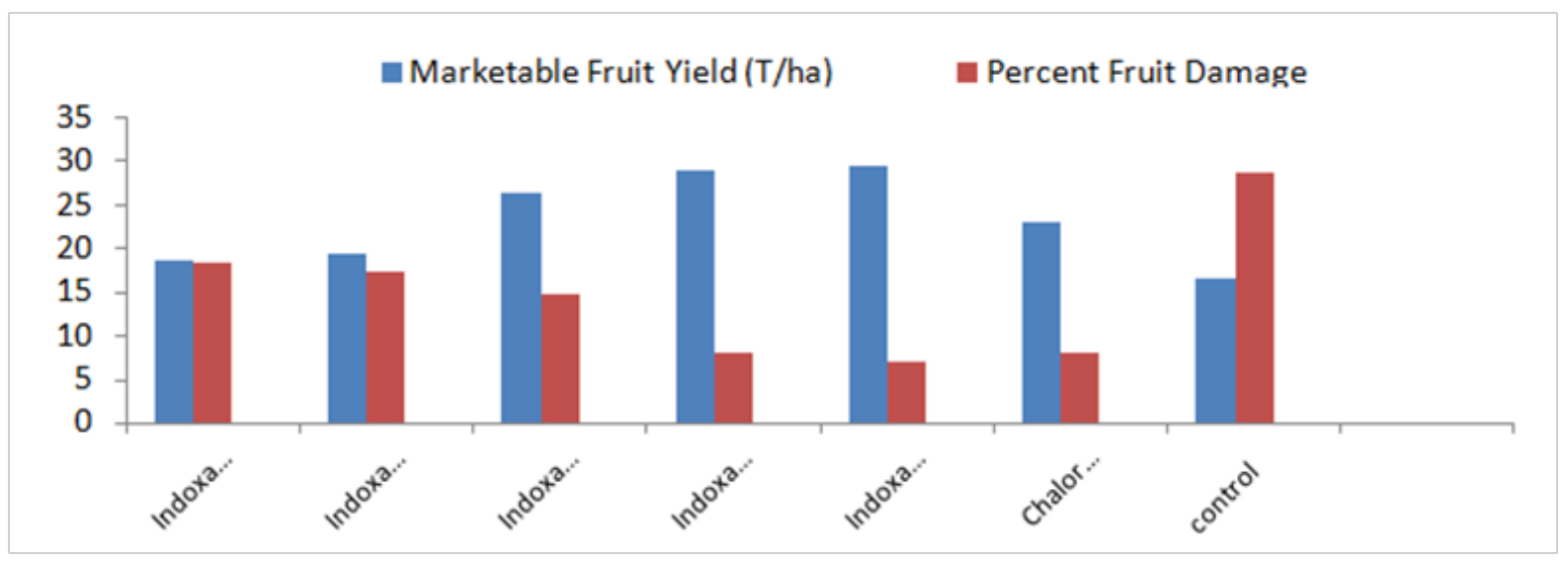

Figure I Effect of indoxacarb on fruit damage and marketable fruit yield of tomato.

\section{Results and discussion}

The results revealed that the larval population of $H$. armigera before the spray did not have any significant difference among different treatments.

\section{Fruit damage}

The larval population of $H$. armigera before the spray did not have any significant difference among different treatments. The percent damage of fruits by $H$. armigera was summarized in Table 1 which shows original as well as angular transformed data. Based on analysis of angular transformed data the lowest fruit damage was observed in Indoxacarb 75 and $60 \mathrm{~g}$ a.i./ha dosage with 7.0 and 8.0 per cent fruit damage. Indoxacarb $50 \mathrm{~g}$ a.i./ha was at par with and Chlorpyrifos having 14.66 and 11.83 per cent damage respectively. Indoxacarb at 30 and $40 \mathrm{~g}$ a.i./ha though had significantly lesser fruit damage (18.33 and 17.50 respectively) but these dosage were less effective compared to Chlorpyrifos. As far as percent of fruit damage over the untreated control is concerned maximum reduction in damage $(83.17 \%)$ was obtained with Indoxacarb $75 \mathrm{~g}$ a.i./ha followed by $60 \mathrm{~g}$ a.i./ha (71.89\%) and Chlorpyrifos (58.56\%). Indoxacarb at 30, 40 and $50 \mathrm{~g}$ a.i./ha reduced the per cent damage by $35.94,40.57$ and 48.72 per cent respectively. Kranthi et al., ${ }^{16}$ suggested the indoxacarb can be used on 90 and 120 day old crop to manage $\mathrm{H}$. armigera. The study showed that the indoxacarb is more toxic to H. armigera compared to spinosad. For second in star larvae of $H$. armigera, 400ppm spinosad can give maximum mortality (4.667), while 200ppm of indoxacarb can give complete mortality after 48hours. ${ }^{17}$ Indoxacarb controls efficiently most of the larval stages of Helicoverpa armigera by stopping the feeding of the insect which causes the immobility and the death within 24 to $60 \mathrm{~h}$. A rate of $37.5 \mathrm{~g}$ of active ingredient per hectare allows a good protection of tomato against Helicoverpa armigera. ${ }^{18}$ Indoxdcarb@50g ai/ha was found effective in all the test of doses in controlling the diamondlldck moth in cabbage. Among the different doses of Indoxacarb evaluated foliar spray@50g ai/ha recorded lowest larval population. ${ }^{19}$

\section{Marketable fruit yield}

Indoxacarb at 60,70 and $50 \mathrm{~g}$ a.i./ha dosage yielded the highest yield of marketable fruits $29.16,29.50$ and 26.5 tons/ ha, respectively. These three dosage of idoxacarb better than that of Chlorpyrifos (23.00 tons/ha). However, Indoxacarb at lower dosage i.e. 40 (19.33 tons/ha) and $30 \mathrm{~g}$ a.i. /ha (18.66 tons/ha) was at par with the untreated control (16.66tons/ha). Bharpoda et al., ${ }^{20}$ revealed that among the different insecticides studied, indoxacarb sprayed on ' $\mathrm{H}$ 6' cotton at $75 \mathrm{~g}$ a.i. /ha showed significant superiority to the rest of the insecticides in terms of giving higher protection to buds and bolls of cotton crop against bollworms. The effectiveness of indoxacarb was also reflected on 
seed cotton yield $(2055 \mathrm{~kg} / \mathrm{ha})$. The different sequential application of microbials and neemazol were equally effective as that of sequential application of synthetic chemical insecticides viz., endosulfan 35 EC(@350g a.i./ha), quinolphos25 EC(@250g a.i./ha) and indoxacarb 14.5 SC (@75g a.i./ha) in reducing H. armigeralarval population and fruit damage. ${ }^{21}$ The significant reduction in larval population

Table I Effect of insecticides on fruit damage and marketable fruit yield of $H$. armigera in protected treatments as compared to unprotected treatments after spraying of effective insecticides, which ultimately increased 69.98 per cent in grain yield $(683 \mathrm{~kg} / \mathrm{ha})$ in protected treatments. 41.17 per cent loss in grain yield could be avoided by giving proper protection against $H$. armigera on chickpea. ${ }^{22}$

\begin{tabular}{llll}
\hline S. No. & Treatments & Marketable fruit yield (T/ha) & Percent fruit damage \\
\hline 1 & Indoxacarb 14.5 SC@30 g a.i./ha & $18.66(25.56)$ & $18.33(25.32)$ \\
2 & Indoxacarb 14.5 SC@40 g a.i./ha & $19.33(26.06)$ & $17.50(24.17)$ \\
3 & Indoxacarb 14.5 SC@50 g a.i./ha & $26.50(30.97)$ & $14.66(22.45)$ \\
4 & Indoxacarb14.5 SC@60 g a.i./ha & $29.16(32.67)$ & $8.00(16.38)$ \\
5 & Indoxacarb 14.5 SC@75 g a.i./ha & $29.50(32.86)$ & $7.00(15.24)$ \\
6 & Chlorpyriphos 20 EC@500 g a.i./ha & $23.00(28.61)$ & $11.83(19.91)$ \\
7 & control & $16.66(24.05)$ & $28.66(32.55)$ \\
$\mathrm{CD}(\mathrm{P} \leq 0.01)$ & $5.29(3.53)$ & $3.53(4.68)$ \\
$\mathrm{CD}(\mathrm{P} \leq 0.05)$ & $3.82(2.84)$ & $2.54(3.37)$ \\
\hline
\end{tabular}

\section{Phytotoxicity}

All the treatments treated with Indoxacarb including 150 and $250 \mathrm{~g}$ a.i./ha dosage did not show phytotoxic effect. No leaf scorching, plant and fruit deformity or flower damage was observed indicating. There by its safety to tomato variety pant type-3.

This can be concluded that considering larval control, damage to the fruits and ultimately the yield of marketable fruits as well as plant safety, Indoxacarb can be used at 60 or $75 \mathrm{~g}$ a.i./ha dosage.

\section{Acknowledgements}

None.

\section{Conflict of interest}

The author declares no conflict of interest.

\section{References}

1. Zalucki MP, Daglish G, Firempong S, et al. The biology and ecology of Heliothis armigera (Hubner) and $H$. punctigeraWallengren (Lepidoptera:Noctuidae) in Australia:what do we know? Australian Journal of Zoology. 1986;34(6):779-814.

2. Zalucki MP, Murray DAH, Gregg PC, et al. Ecology of Helicoverpa armigera (Hubner) and $H$. punctigera (Wallengren) in the inland of Australia:larval sampling and host plant relationships during winter and spring. Austral J Zool. 1994;42:329-346.

3. Reed W and Pawar CS. Heliothis:a global problem. In: Reed W, et al. editors. Proceedings of the International Workshop on Heliothis Management. Patacheru, India; 1982. p. 9-14.

4. Fitt GP. The ecology of Heliothis in relation to agroecosystems. Annual Review of Entomology. 1989;34:17-52.
5. Sharma HC. Cotton bollworm/legume pod borer Helicoverpa armigera (Hübner) (Noctuidae: Lepidoptera): biology and management. Crop protection compendium. International Crops Research Institute for the Semi-Arid Tropics; 2001.

6. Suryawanshi DS, Bhede BV, Bhosale SV, et al. Insecticide resistance in field population of American bollworm, Helicoverpa armigera Hub. (Lepidoptera: Noctuidae). Indian Journal of Entomology. 2008;70(1):4446.

7. Dhandapani N, Umeshchandra RS, Murugan M. Bio- intensive pest management (BIPM) in major vegetable crops: an Indian perspective. Food Agriculture and Environment. 2003;1(2):333-339.

8. Tewari GC, Krishnamoorthy PN. Yield loss in tomato caused by fruit borer. Indian J Agric Sci. 1984;54:341-343.

9. Srinivasan PM. Control of fruit borer, H. armigera (Hb.) on tomato. Indian Journal of Horticulture. 1959;16:187-188.

10. Singh H, Singh G. Biological studies on Heliothis armigera (Hübner) in Punjab. Journal of Entomology. 1975;34:154-164.

11. Selvanarayanan V, Narayanasamy P. Factors of resistance in tomato accessions against the fruit worm, Helicoverpaarmigera(Hübner). Crop Protection. 2006;25(10):1075-1079.

12. Latif M, Aheer GM, Saeed M. Quantitative Losses in Tomato Fruits by Heliothis armigera $\mathrm{Hb}$. Abstr. PM-9. Third International Congress of Entomological Science. Pakistan Entomological Society, Islamabad: National Agricultural Research Center; 1997.

13. McCann SF, Annis GD and Shapiro R. The discovery of indoxacarb: Oxadiazines as a new class of pyrazoline-type insecticides. Pest Manag Sci. 2001;57(2):153-164.

14. Hewa-Kapuge S, McDougall S, Hoffman AA. Effects of methoxyfenozide, indoxacarb, and other insecticides on the beneficial egg parasitoid Trichograma nr. brassicae (Hymenoptera:Trichogrammatidae) under laboratory and field conditions. J Econ Entomol. 2001;96(4):1083-1090. 
15. Studebaker GE, Kring TJ. Effects of insecticides on Orius insidiosus (Hemiptera:Anthocoridae), measured by field, greenhouse and petri dish bioassays. Florida Entomol. 2003;86(2):179-185.

16. Kranthi KR, Kranthi NR. Modelling adaptability of the cotton bollworm, Helicoverpa armigera (Hübner) to $\mathrm{Bt}$ cotton in India. Current Science. 2004;87(8):1096-1107.

17. Khan RR, Zia K, Salman W, et al. Efficacy of tracer $240 \mathrm{SC}$ and steward $150 \mathrm{SC}$ against first and second instar larvae of Helicoverpa armigera by using the leaf dip method. Journal of Plant Protection Research 2010;50(4):438-441.

18. Abid R, Cagnieul P. Indoxacarb:a new active insecticidal ingredient against fruit moths. Colloque international tomato sous abri, protection integree agriculture biologique, Avignon, France; 2003. p. 188-191.
19. Rai AS, Kumar Akhilesh, Satapathy S, et al. Efficacy of Indoxacarb 15 EC in the control of diamondback moth, Plutella xylostella L. in Cabbage. Vegetable Science. 2007;34(2):160-162.

20. Bharpoda TM, Sisodiya DB, Patel JR. Effectiveness of indoxacarb $15 \% \mathrm{sc}$ in controlling insect-pests of ' $\mathrm{H}$ 6' upland cotton (Gossypium hirsutum). Indian Journal of Agricultural Sciences. 2003;73(4):203-205.

21. Ravi M, Santharam G, Sathiah N. Ecofriendly management of tomato fruit borer, Helicoverpa armigera (Hübner). Journal of Biopesticides. 2008;1:134-137.

22. Deshmukh SG, Sureja BV, Jethva DM, et al. Estimation of yield losses by pod borer Helicoverpa armigera (Hübner) on chickpea. Legume Research. 2010;33(1):67-69. 